\title{
REFUGEE CHILD IN EGYPT: VULNERABLE OF THE VULNERABLE IS IT A WAY FOR EMPOWERMENT? ${ }^{1}$
}

\author{
Wafaa El Sherbiny ${ }^{2}$ and Massoud Amany ${ }^{3}$ \\ 2Prof Dr. Ms, Cairo University, Egypt, wafaaelcherbini@feps.edu.eg \\ ${ }^{3}$ Prof Dr., Cairo University, Egypt, amanymasod@feps.edu.eg
}

\begin{abstract}
The research seeks to understand and analyze the process of refugee children to neighborhood states and whether the refuge policy is implemented in a manner that allows it to achieve its main objective: a protection tool for refugee children who are mostly in need of protection and a proper mechanism of social responsibilities in under developing country. The research also seeks to evaluate the impact of recipient states policies and the process of its implementation on the capacity of recipient countries to take in more refugees and on the refugees who remain in these countries.
\end{abstract}

Keywords: Children refugee, Egypt.

\section{INTRODUCTION}

No doubt, that Egypt has witnessed dramatic political changes after $25^{\text {th }}$ of January revolution. However, Arab spring carries strong winds that may harm children in the Arab region. More than One million child moved by force to their own neighbor/ territorial state, left their school, street friends, their toys, homes and their childhood sweaty memories to "wonder" and ambiguous lands even if its named "Arab country"...

If there is a common agreement among development scholars that hard to deal with vulnerable group, the hardest is studying academically vulnerable of vulnerable people in a developing country with its economic chronicle problem and its national improper context for solving it. Although the answer is beyond the limited scope of this preminarly paper, canalizing the main causes that hinder activating the code of rights for refugee child, and exploring what do refugee children need should be taken seriously as guideline recommendations for the decision maker to humanize the dimension of this issue..

Methodologically, refugee child issue cannot be discussed away from the evaluation of the public policy set of the guest state and serious empirical studies clarified what does refugee child need and what he wants in his own second home!

This short preminarly paper is aiming to throwing the light on the situation of the child refugee in Egypt, the governmental role in dealing with this issue and why the new political change has to produce new and more human vision to deal with the refugee children regardless their race, religion, language and even their color.

The paper is divided into 6 sections. After this introduction, section two will outline the conceptual framework of the paper. Section three will look at the Egyptian government efforts and NGOs in dealing with refugee children by focusing on challenges faced .Section four forms the research background, it will provide

\footnotetext{
${ }^{1}$ My thanks go to Ethar Semeada ma student in FEPS, Cairo University for their academic help. My deepest thanks and gratitude's to the six individuals sample refugees that accepted to share me their stories towards their stay in Egypt and whose words included in this paper...
} 
information about the child refugee accessibility to the main social services (Education -Health care). In Section five of this paper, the empirical part will be presented by interviewing a focus group of refugee children about the main question of the research: what does refugee child need and what he wants in his own second home? The paper will not be limited to discuss and analyze the outcomes of interviews but it will present in the last section some recommendations to the Public Policy makers in Egypt.

\section{CONCEPTUAL FRAMEWORK}

In understanding the refugee child issue, it is vital to start with differentiating between three main legal statuses and thus associated rights:

(1) A refugee: according to the 1951 Refugee Convention is someone who is outside their country of origin or habitual residence who is unable or unwilling to return to their country of origin owing to a wellfounded fear of being persecuted for reasons of race, religion, nationality, membership of a particular social group, or political opinion. The 1969 OAU Convention (which only applies to African refugees) adds the factor of civil war or war-raven disturbances to the nexus of the definition. Both the 1951 and 1961 refugee conventions do not cover Palestinian refugees and thus Palestinian refugee children are excluded from the protection provided under both conventions. The UNHCR mandate is the one that covers them and grants them protection. Any asylum-seeker that is recognized as a refugee in need of protection and with a genuine refugee claim is protected by the jus cogens norm/principle of nonrefoulement under international law that prohibits the country granting refugee status and protection from returning/deporting the refugee to his country of origin/habitual residence.

Hence, refugee is the person, who is enforced to flee due to violence,

War or insecurity

$A(n)$ (internally) displaced person: internally displaced persons are those who have been displaced within their own country of origin or habitual residence due to reasons that may not be covered under the refugee conventions. A displaced person is someone who is forced to leave his native place or country but remains without a legal status until he/she seeks asylum and recognized as a refugee and thus granted particular rights as stipulated under the refugee conventions to which the country (in this case Egypt) is a signatory. A displaced person can be both an economic or environmental migrant (which describe their causes for leaving their country), however both statuses of migration are not covered by the refugee conventions to which Egypt is a signatory. Thus, both economic and environmental migrants are usually denied refugee status at UNHCR in Egypt and would thus fall under the statuses of illegal migrants or foreigners depending on the mode of entry to Egypt.

(2) Foreigners: are those who enter the country legally under a defined legal status and purpose such as (tourism, studies, visit, residence, etc.) and whose rights are defined and guaranteed by national laws.

The particular focus of this paper is the first category, namely refugees, and the rights enjoyed in particular by refugee children.

Within the first category, three sub categories of refuge children are in Egypt. They are, children of refugees (accompanied children); the children refugee (unaccompanied children) and the children refugee who are separated from their families (separated refugee children). Although each category has its own difficulties and sufferings that are required high quality of methodological tools to be studied academically and recommended outstanding level of institutional coordination practically which are beyond the scope of this preliminary paper? However, the refugee child as a term is so controversial especially for the decision makers that their definitions, which are highly politicized, are not always matching with the academic ones.

On one side, the researcher stated that the United Nations High Commission for refugees (UNCHR) regional office in Cairo is the only institution that cares for the refugee children in general and for the separated refugee children in specific while the programs of the UNICEF in Cairo are not interested in non-Egyptian children issues.

On the other side and politically speaking, The Egyptian state has not reviewed its previous policy towards the refugee child. It preferred to be soft and weak state for more than four decades and being delighted with throwing the responsibilities on the burden of international organization, NGOs to solve the refugee problems Legally speaking, Egypt has signed and ratified lots international / regional conventions and agreements that focused on the rights of refuges and the readiness to protect them, but practically, when refugees threat the internal political stability, leaders preferred to forget all tolerance and mercy discourse and put all the signed agreements aside...

In this paper, the researcher claims that gap between "what ought to be" and "what is" in refugee issue is so wide and deep... Along Egyptian historical experience, the status of adult refugee that they might be able to protect themselves and protest against any unfairness addressed by the Egyptian state was extremely hard. Thus, what is about the children of this vulnerable group? 


\section{EGYPTIAN GOVERNMENT EFFORTS AND NGOS IN DEALING WITH REFUGEE CHILDREN}

Egypt is signatory to the 1951 Convention Relating to the Status of Refugees and its 1967 Additional Protocol in addition to the AOU 1969 Convention (OAU Convention Governing The Specific Aspects Of Refugee Problems In Africa). In the absence of a national asylum system, all activities relating to the registration, documentation and determination of refugee status (RSD) are carried out by the United Nations High Commissioner's Office for Refugees (UNHCR) office in Egypt as per the Memorandum of Understanding (MoU) signed with the Government of Egypt in 1954.

Since 1952 the Egyptian government has delegated the responsibilities for both adult and child refugees to (UNCHR) regional office in Cairo. The UNCHR in Cairo is assigned to evaluate the situation of the refugees and provides them with humanitarian assistances. In addition, it works on relocating these refugees to a third country. (Laura Maxwell \& Aya El Hilaly, separated refuges children in Cairo, A rights based analysis, working paper No. 5, September 2004, The American University in Cairo, Forced migration and refugee studies, p. 7). The convention of 1951 related to refugees, in addition to its protocol issued in 1967, and the convention on the rights of the child in 1989, is the only two instruments that are interested in the welfare of the refugee children. But As opposed to the items of the Convention on the Rights of the Child (1954), the Egyptian programs do not cover the non-Egyptian children...even the UNICEF, it also does not target the refugee children; it even objected the suggestion of UNCHR to cooperate.

Later, Egypt has signed these two conventions in 1998 and 1991 respectively. In 1969, Egypt signed also the items in the Charter of the Organization of African Unity, which govern the issue of the refugees in Africa and those in the African Charter of the rights and Welfare of the Child in 1981. As for The Arab Charter on Human Rights, it refers only to the Arab refugee children. The four Geneva conventions and the International Covenant on Civil and Political rights are among the other international agreements related to the subject.

The International Convention on the Rights of the Child depends on four main principles (Hilaly\& Maxwell, p. 11)

The right to nondiscrimination (Article 2)

The best interest of the child (Article 3)

The right to survive and development (Article 6),

The right of the child to participate and share views (Article 12).

The right of "nondiscrimination" recognized that no child on the territory of the state- should be denied rights due to his/her race, sex, language, immigration or other status. The most general standards are the ones mentioned in the Report on the Refugee Children issued in 1994.

Egypt made the following reservations on significant articles of the 1951 conventions:

1. Egypt formulated a reservation to article 12 (1) (Domicile).

2. Concerning articles 20 (rationing) 22 (paragraph 1) (elementary education), 23 (public relief) and 24 (labor legislation and social security) of the Convention of 1951, the competent Egyptian authorities had reservations because these articles consider the refugee as equal to the national.

As such, as per the Egyptian Government's reservations to 1951 Refugee Convention refugees are not given the same rights as nationals even after recognition by UNHCR RSD process as genuine refugees in need of both protection and assistance. This directly affects refugee children (especially in the part relating to the right to education, where refugee children are not as per their status given the right to free education in public schools) or indirectly (especially in the parts relating to public relief, labor legislation and social security).

The reservations on articles 20 and 22 prevent refugee children from same treatment as nationals and particularly prevent them from accessing elementary education in public schools. This stands in contradiction with Article 7 of the Declaration of the Right of the Child to which Egypt is a signatory, which gives the child the right to free education.

The former Egyptian president Mohamed Hosni Mubarak has declared the period between 1989 and 1999 as the First Decade for the Egyptian Child; this declaration has been renewed in 2000. Egypt has claimed for long those children affairs top its social development plan. NGOs, governmental and intra governmental institutions play a major role in the domain of children rights, but their efforts - despite some exceptions - are directed only towards the Egyptian children. The Article 35 of the Egyptian constitution recognizes the right for asylum seeking, but generally, any local or international law does not govern asylum. In addition, there are no juridical verdicts that deal with the refugee children in specific.

Institutionally, the National Council for Childhood and Motherhood is the only governmental foundation that deals with the issues of children. According to Article 145 of the Child Law, it is the only foundation responsible for monitoring the application of this law. It also carries on the responsibilities of policy planning and the activities related to the development and growing up of children, as well as organizing those activities and evaluating them. In the period before 2004, NCCM's projects and programs dealt with the needs of the 
Egyptian children, but in January 2004, the officials of the council announced that the refugee children would then be included in their agenda. In cooperation with the ministry of health, the council has established a clinic, 4, $5 \mathrm{~km}$ outside Cairo, to serve Egyptians and refugees equally. (El Hilaly \& Maxwell, p.14-16)

Challenges that refugee children have faced in Egypt:

The right of refugees is grounded in the items of international law, but refugees, in general, are used to share poor people their districts and areas, live in the margins of host society, adopted the same view of the government that they will stay in Egypt for short time and their presence is transitory one.

Although the refugees have been allowed to settle temporary among people of the host community, resettlement in a third country is the preferable solution for the Egyptian government. That is why so hard for the majority of refugees to fully integrated in hast society and transmitted the same feelings to their children. Due to these feelings, refugees are not banned officially from working, they cannot get work permits, and thus children are denied law protection. In addition, NGOs, which work in the field of children labor, concentrate only on the Egyptian children not the refugees.

\section{CHILD REFUGEE AND ACCESS TO SOCIAL SERVICES}

\subsection{Education}

Although children who attend schools are more able to report assaults, refugee children rarely join official schools and the children who are separated from their families are even less lucky. (Maxwell \& el Hilaly, p. 34/35)

In addition, school staff would refrain from coordinating with UNCHR as far as assaults are concerned. One of the staff in an ecclesiastic schools says that the assault cases are reported to the group to which the child belongs: "In these cases we call the family of the child, we do not deal with the parents but leave the matter to the tribe or group chiefs to solve the problem. "According to a decree issued by the Egyptian ministry of education in 1992, those who benefit from the scholarships offered by UNCHR such as the children of the political refugees, Sudanese, Jordanian and Libyan children have the right to join the Egyptian governmental schools, but the decree does not mention children who belong to other nationalities .

The decree states that those children have to present copies of their birth certificates, certificates from the schools they attended back home, certificates of their original nationalities, valid living permits and letters of approval from their embassies.

In 2000, a decree by the minister of education has been added to it stating that the Sudanese children who present required documents are entitled to attend primary and secondary Egyptian schools.

As for nationals of other countries, they are required to get a letter from the department of refugees in the Egyptian ministry of foreign affairs...Non Egyptian children are denied the social services offered in Egypt either according to law or due to actual circumstances and behaviors.

In addition, the Egyptian NGOs that deal with children do not target the refugees and are unaware of the existence of the refugee children and their needs.

Even if those conditions are to be cancelled, many obstacles stand in the way of the children's integration in the society. The Egyptian education system suffers from many problems including the big number of students, the problem that obliged some schools to have students according to a shift or rotation plan.

In 2000, a national survey took place on Egyptian children from six to 15 years old. The survey showed that $14 \%$ of the girls and $8 \%$ of the boys are not attending schools.

Therefore, practically, school managers would ban the refugee children from joining the schools, even those who managed to obtain the required documents, based on the principle that refugees cannot be admitted to schools to occupy places that may be filled by Egyptians.

There are three main alternatives: schools belonging to national NGOs or churches, Islamic schools, the schools of the foreign nationals that work in Egypt.

Almost 3000 refugee attend the eight schools that belong to the church in Cairo. In those schools, education is in English or Arabic. Almost all students in those schools are Sudanese, especially Christians from the south of Sudan. Other children from other nationality are denied attendance due to language differences or due to the wrong belief that those schools are for the Sudanese or the Christians only.

The biggest school among those is Saint Luangwa for Primary Education in the Sacre Coeur Church (known as Elsakakiny church).

As for Muslim refugee children, they can attend one of the Islamic schools in Cairo. Some of the subjects to the survey arrived to Cairo with a student visa then joined the residence belonging to Elazhar University which provides free of charge education. Students also get 80 Egyptian pounds as a monthly pay (around 13 US Dollars).

Some students managed to get a place to stay in residence that belongs to the school. The school claims that it provides primary and secondary education but it focuses mainly on teaching the Quran. 
Classical Arabic is the official language for teaching, but students who do not speak Arabic fluently attend lower level classes, lower than their actual standard. Students - young men and children - mentioned that they attend the classes for no reason other than keeping the legal living permits they are granted while waiting for approval on their asylum requests. (Maxwell \& El Hilaly, p. 65)

\subsection{Health Care}

In Cairo, refugees - minors and adult - pay to obtain health care in governmental clinics and hospitals. However, there is one exception, which is a project by the National Council for Childhood and Motherhood, it is an outstanding project held $4500 \mathrm{~km}$ outside Cairo where refugees and Egyptians can get health care equally. In addition, UNCHR finances its executive partner Caritas to provide accepted refugees with low cost health care.

Whereas refugee children who are separated from their families are entitled free of charge health care via Caritas but the children seeking asylum are denied the aid provide by UNCHR to cover their health care expenses.

There are 5 ecclesiastic schools for the refugee children that are equipped with medical centers: (The Sacre Coeur school in El Sakakiny district and its branches in El Maadi and 4,5 district, kindergarten of Virgin Mary church in the 4,5 district and All Saints church in El Zamalek district ).

Except for the medical center of the All Saints church, those medical centers provide medical services only to the students and staff of the school of the church. (Maxwell \& Hillaly, p. 40)

Then, Refugee children are not allowed to proper access public schools. Instead, they access usually expensive and often unaffordable private schools, which they finance through educational grants offered to them by UNHCR or Al Azhar.

Accordingly, refugee children's parents have to pay the school fees in advance to be reimbursed by the Catholic Relief Services (CRS). While the educational grant covers most of the education fees, the children's parents still have part of the fees to cover, which adds to their financial burdens and often many refugees coming from poor countries (like Sub-Saharan African countries) are unable to afford the remaining fees that they end up leaving their children without education. Exceptions sometimes exist such as in the case of Islamic schools (affiliated to Al-Azhar) that sometimes exceptionally offer Islamic education to refugee children coming from Islamic countries. Another exception was given to the children of Libyans refugees (fleeing their country in the advent of the Arab Spring revolution and civil war) whose parents were exceptionally given financial assistance by the Egyptian Government and their children the right to education in public schools. The Egyptian Government asked that Libyan refugees not be registered at UNHCR (for their protection) and therefore their situation remains unknown ambiguous. Syrian refugees have also not been registered by UNHCR and they are believed to get the same treatment of Libyans (no further information available in this regard except at the Egyptian Ministry of Foreign Affairs).

Refugee community school exists in the Ethiopian and Sudanese communities, however the quality and efficacy of the education offered by these schools is largely unknown and is understudied and not monitored by neither the Egyptian Government nor UNHCR.

Then, the Egyptian governmental reservation on convention of 1951, articles 20, 22, 24 including restriction in access to public education, health care and other social service.

\section{INITIAL QUESTIONNAIRE}

Based on the difficulties to study the refugee's children theoretically and believing that vulnerable people should have a say in their future and the state policy to deal with them, the researcher finds it is misery to explore how child refugee thinks and what does he need and want. Six children were interviewed for this paper. The respondents were aged between 10 and 15 at the time of this interview. They were between 7-9 years old when they first arrived in Cairo. The sample included children from five countries, Sudan, Iraq, and Somalia. Two of respondents were female.

Alienation feelings and refugee child's image on the host country are the main indicators in measuring the refugee child perception about Egypt... By "focusing group" interview approach and via 3 direct questions, the researcher tried to reach the answer of how the child refugee feel towards Egypt and Egyptian policy towards refugees children?

1 - Do you feel as an alien sometimes?

2- Can you recognize the Egyptian flag or the name of the Egyptian president?

3-Do you wish to settle down in Egypt eventually? If YES, why? If NO, what is the country you wish to settle down in?

4-Do you share any decision related to your status as a refugee child in Egypt?

http://ijasos.ocerintjournals.org 
Regarding the second question, all individuals have confirmed that they can recognize the Egyptian flag and president and aware of the updated events in Egypt. While the six individuals replayed with big NO to the third question!

"I don't wish to live in Egypt, I have no future here. I cannot even practice the hobby I do not like because I found no professional trainers or clubs where I can exercise Kung Fu, while Shrift liked to go to Australia because the education system in Egypt is not efficient enough.

One of respondents "Faisal" linked his desire to not stay in Egypt to what the Egyptians themselves are suffering from socially, economically and in regards to education, he assured that Egyptians need to focus on their own problems ...."... This is the reason why I do not wish to go on living or attend schools here".

The two female respondents" Zaynab and Afnan do not wish to live in Egypt; they wish they can go home because the future there is brighter especially about education or work.

Out of this deep interview with respondents, the results show the child refugees rarely participate in decision making about their own situation as refugees, in arranging their living or education conditions.

The respondents lack of interest and loss of motivation for continuing their education due to the difficulties that exist in being admitted on equal standing as Egyptian nationals at universities upon completing their school education, partly due high fees being applied on them as foreigners, despite their different status (and difficult financial situation) as refugees... or because the lower quality of education they are provided with compared to their own country.

In addition, Refugees have complained of hostilities by the Egyptian society on basis of nationality and color. Some refugee children (especially those that are racially and ethnically different, particularly from Black Africa) expressed during their interview and out of their vocabularies that they face discrimination, hate crimes and harassment (particularly refugee girls) due to their skin color. South Sudanese refugee children expressed physical threats by groups known as the "Lost Boys" on their way to school

Five individuals out of six replayed they feel alien.

"...I face a lot of problems in copying with people in Cairo. For instance, the Egyptians are used to acquire their rights via arguments and fights but I avoid such way, not due to my fear or weakness, but to avoid problems. In the streets, I am also called few names such as Shikabala, the black or chocolate due to my color. In spite I dislike such behaviors, I do not react..." Adam said.

He added..."I also like Kung Fu but there is a lack of facilities to practice it in Egypt, and there are very few professional trainers... I need to back home to do it..."

On the contrary, of what Adam said Sheief confirmed he does not feel alien ..."I attend an Egyptian school and has Egyptian friends with whom he can play and interact normally..."

According to their vocabularies, language was the main cause for such alienation according to some answers of the study group ..."...when I arrived Egypt I faced the big problem of the language difference. The language differs from my own and that made it difficult to deal with my teacher and with the Egyptians generally..." Faisal said.

He added in so optimistic view regarding the future..." I am sure as my friends said this problem has been solved when I learned the Arabic language and mastered the Egyptian accent... ".The same idea of disability to cope with the life in Egypt and the sever alienation feelings was confirmed by Mohamed when he repeated "My problem is not related to school but lies outside its walls, It is hard to deal with people and with the numerous arguments and fights..."

However, learning language was not the good solution for the alienation problem for some respondents, Zaynab, for example, assured that she had the same feelings of alienation inside and outside the school... "..I had a problem dealing with one of my Egyptian female classmates; she used to treat me badly because I am not Egyptian. I attracted her attention to that but she continued dealing with me in this way. Eventually, I had to treat her the same way but later I had to end up my relation with her".

One individual linked the alienation feelings with the lack of social services that offered by Egyptian government,"...My relation with others is my own problem in Cairo community. Sure I feel as an alien because I could not have a normal access to educational and medical services" Afnan said.

\section{RECOMMENDATIONS}

- Establishing or creating "Egyptian institutional entity" such as supreme council for refugee child is highly recommended to institutionalize protection mechanism for child refugee as a part of public policy issue.

- The Egyptian government must amend the ministerial decree governing the care to enable the refugee children to get it from the members of the society legally. 
- The benefits are not only limited to monitor the child care activities offered by the government, but includes expansion of the government responsibility to monitor the ways through which the children are getting accurate education and health care.

- There is a need to enhance the cooperation among the Egyptian NGOs, the government, UNCHR, the other governmental organizations - specially the UNISEF - and the organizations that work in the original countries of the refugees to facilitate the process of family recognition and a safe return of the children who are deprived from the chance to return home.

- Allowing refugee children to study in public schools and universities on equal standing as nationals (at least, for the elementary levels) according to article 7 of the Convention on the Rights of the Child.

- Increasing university scholarships for refugees or granting refugees the right to equal treatment at university level based on merit.

- Establishing a special organization that offers psychological and legal assistance to refugee children in general and unaccompanied minors, in particular, in helping them deal with their particular trauma and in assimilating and integrating within the Egyptian society.

- The organizations that are working in refugee child domain should receive and monitor cases of discrimination and abuse faced by refugee children as well as to assist them psychologically and legally.

- The organizations may also monitor the economic situation of refugees and their financial situation and as such the socio-economic situation of refugee children. In the case of refugees, the Government should grant them the right to work and assist them in finding work (if possible) within the community to be able to sustain their children.

- The council for childhood and motherhood may also establish a special hotline (with professional psychotherapists aided by translators) that can provide refugee children with psychological assistance and in need of legal intervention legal assistance.

- Raising awareness of the refugee situation and causes through media, education and government training. There should be a special target for people who directly deal with refugee (medical doctors at hospital, government officers and police officers). The refugee cause should be added in educational material.

- Encouraging refugee's small projects (could be through loans) with the aim of improving the living conditions of refugee children.

\section{REFERENCE LIST}

Maxwell, Laura \& Aya El-Hilaly. (2004). "Separated Refugee Children in Cairo". A Right-Based Analysis. Forced Migration and Refugee Studies Program. Working Paper No.5. American University in Cairo. 